\title{
INTEGRATING BUILDING INFORMATION MODELLING AND INTELLIGENT CONTRACT TO PAYMENT PROCESS UNDER CONVENTIONAL PROCUREMENT IN MALAYSIA.
}

\author{
Rozana Mohamed Salleh* \\ Department of Quantity Surveying, Faculty of Built Environment and Surveying \\ Universiti Teknologi Malaysia \\ Malaysia \\ Nur Emma Mustaffa \\ Department of Quantity Surveying, Faculty of Built Environment and Surveying \\ Universiti Teknologi Malaysia \\ Malaysia \\ Nafisah Abdul Rahiman \\ Department of Quantity Surveying, Faculty of Built Environment and Surveying \\ Universiti Teknologi Malaysia \\ Malaysia
}

*Corrosponding author's Email: oja.salleh@gmail.com 


\section{$R_{i}$}

\section{Science Proceedings Series \\ (SPS) \\ www.readersinsight.net/SPS}

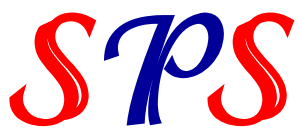

\section{R E S E A R C H H I G H L I G H T S}

Conflict caused by payment issues are common in construction industry. A lengthy payment process issue is a common phenomenon especially in public work projects, which commonly opt for conventional contracts. Delay in payment process have caused many contractors not being able to receive payment within the stipulated time. In turn, it may affect the contractor's cash flow and eventually ended up causing delays in project completion. The effect of technological advances has brought significant changes to the construction industry, which is year after year becoming increasingly complex. Therefore, in the era of technology and digital, there are many management systems which have been established and introduced amongst construction players for the convenience of managing and administering construction projects. The introduction of Building Information Modelling (BIM) is to establish a centralised information system, which improves the collaboration, communication and integration between interdisciplines in construction industry. The development of digital technology of Intelligent Contracts will bring great potential as an automate support system in BIM management process. These combinations create possible solutions towards payment conflicts in the construction project, through integration of BIM and Intelligent Contracts that may help to reduce the unnecessary procedure and interference that prolong the payment process. The analysis revealed that the adoption of BIM and Intelligent Contracts attributes in payment process under conventional procurement could improve the efficiency and reduce the time by eliminating unnecessary procedure and third parties interference along the process.

\section{RESEARCH OBJECTIVES}

The main purpose of this study is to discuss the process in the conventional contractual procedure in relation to the causes of delay in progress payment. Therefore, the specific objective of this study is to explore what are the effects of integrating BIM and Intelligent Contracts attributes in conventional payment process.

The significance of the study is to highlight and understand on the attribution of BIM and Intelligent Contracts in order to improve the effectiveness of payment process under the conventional projects. In addition, this study may provide new knowledge towards meaningful collaboration through BIM implementation and exploitation of automated contract system.

\section{MATERIALS AND METHODS}

There is an immediate urgency to understand the need having efficient Intelligent Contract in the Malaysian construction industry in order to facilitate BIM implementation in the future. This is a descriptive study and the methodology used is essentially on review of the literature in relation to payment processes in conventional contract, BIM management system and attributes of Intelligent Contracts.

The data collection for literatures were taken from various sources to get a complete information and understanding for the main purpose of this research. Most of the reference materials are obtained from books, conference proceedings publications, journal articles, internet sources, dissertations, and other associated published study provided information on issues associated with Conventional Contracts; Progress Payment Claims; BIM implementation; and Intelligent Contracts globally and specifically in Malaysian construction industry. 


\section{$R_{i}$}

\section{Science Proceedings Series (SPS) \\ www.readersinsight.net/SPS}

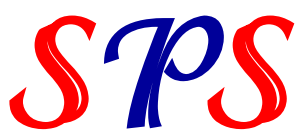

\section{RESULTS}

In due course, BIM is a usable technology for construction projects that has benefited the Malaysian construction industry (1). BIM might be a solution to technological developments (2), (3) and by incorporating Intelligent Contracts; it will bring the ability to deliver a conventional projects more efficient without any unnecessary procedural and multilayers intervention (4). With an adequate standard forms of contract which is handled digitally and intelligently, a number of common issues can be reduced such as inadequate delegation of rights and responsibility, multi layers interference (5), which ended up with communication gap which led to redundancy along the process, which eventually would otherwise dampen down the progress of the project (6). In the long run, the integration between BIM and Intelligent Contracts may produce an efficient, transparent and flawless contracts management system (4),(5).

\section{FINDINGS}

The propensity of adopting BIM and Intelligent Contracts is expected to facilitate the conventional contract administration, especially in addressing the issue of delays in progress payment. The integration between BIM and Intelligent Contracts is believed would strongly support on how a project being organised, managed and controlled. Ultimately, the awareness of the construction players with these combinations is important to ensure the success of the project.

\section{ACKNOWLEDGEMENT}

The authors would like to thank Universiti Teknologi Malaysia for the funding provided under the Research University Grant (GUP: Vot No: Q.J130000.2621.19H74) without which it would be impossible for the authors to finish the study.

\section{REFERENCES}

1 Mahbub R. 2015, Effective Teaching of Technology: Building Information Modelling, Journal of Education and Educational Technology. 2015, ISBN: 978-1-61804-300-9, pp 61-64.

2 Succar B. Building Information Building Framework: A Research and Delivery Foundation for Industry Stakeholder, Automation in Construction. 2009, Vol.18. Iss.3, pp. 357-375.

3 Tekla Corporation [Internet]. BIM Basic Concepts. [Cited 08 August 2016]. Available from: http://www.tekla.com

4 Mason J. Intelligent Contract and Construction Industry. Journal of Legal Affairs and Dispute resolution in Engineering and Construction. 2017, 9 (3), ISSN 1943-4162.

5 Pillai M, Adavi P. Intelligent Contract Management. International Journal of Scientific and Research Publications. 2013, Volume 3, Issue 1, ISSN 2250-3153.

6 Azman MNA, Zuhairi AH, Natasha D, Kamarul AMK, Mohd MNM. [Internet]. Payment Scenario in the Malaysian Construction Industry Prior to CIPAA. 2014. [Cited 10 March 2019]. Available from: https://www.researchgate.net/publication/260244930. 